\title{
FOREIGN DIRECT INVESTMENT IN INDIA-AN INVINCIBLE WAY FOR ECONOMIC DEVELOPMENT
}

\author{
CMA Sandip Basak ${ }^{1}$, Rohan Prasad Gupta ${ }^{2}$, Priyajit Kumar Ghosh ${ }^{3}$ \\ ${ }^{1}$ State Aided College Teacher (Category - I), Department of Commerce, Surendranath College for \\ Women Kolkata, West Bengal, India \\ ${ }^{2}$ M.Phil. Research Scholar, JRF, Department of Commerce, University of Calcutta \\ ${ }^{3}$ NET, M. Com., University of Calcutta
}

Article DOI: https://doi.org/10.36713/epra6968 DOI No: 10.36713/epra6968

\begin{abstract}
Foreign direct investment plays a vital role in the development of a nation. The present research work aims to analyse the impact of FDI inflows on annual GDP and per capita GDP, that is, to understand the impact of FDI on Indian economy since the implication of LPG policy in India. Simple linear regression models has been used for analysis purpose and based on the results, suitable implications has been drawn.
\end{abstract}

\section{BACKGROUND OF THE STUDY}

India is emerging as a preferred destination for Foreign Direct Investment (FDI), half of which is in the manufacturing sector in market value terms, as per the latest census on Foreign Liabilities and Assets (FLA) of Indian Direct Investment companies. India's FDI stock was nearly four times its outward direct investment. With strong cross-border trade linkages, both Indian and foreign cross-border subsidiaries recorded good business growth during 2016-17. The effects of FDI are found to be diversified but dependent on recipient economy's absorptive conditions, including its institutional setup, and the degree of complementarity and substitution between domestic and foreign investment. It promotes economic growth by supporting industrial activity and employment through transfer of technology and physical capital while also stimulating domestic investment. It also fosters global trade and facilitates integration into the global economy more successfully than other modes of capital flows. The market value of the FDI stock (including investment flows and valuation changes) increased by $9.7 \%$ during 2016-17and stood at Rs. 23,387 billion in March, 2017 of which nearly 94\% was held as equity. On the other hand, the stock of Outward Direct Investment declined by $9.8 \%$ during the year to Rs. 5411 billion. Inward FDI has witnessed average annual growth of $14.3 \%$ since 2012-13. In this study, the researchers have taken an attempt to identify the impact of FDI on the annual Gross Domestic Product of India.

\section{REVIEW OF LITERATURE}

Azhar \& Marimuthu (2012) has identified different determinants of FDI. India's stable economic policies, availability of cheap and skilled labour, availability of required infrastructure, sound legal system, availability of large volume of natural resources and existence of unexplored markets has attracted foreign investors to invest in India. Malhotra (2014) has stated FDI policy of India has been gradually liberalised to make the market more invest friendly. It has also supplements domestic capital, technology and skills of existing companies and also helps to established new companies. Vyas (2015) stated that there is a 34\% growth in FDI inflow in 2015 over 2014. Countries like Mauritius (34\%), Singapore (14\%), U.K (9\%), Japan (7\%), Netherland (6\%) having highest FDI investments in India. Researcher stated that FDI has an important stimulus for the economic growth in India. 
Duggal (2017) has found that percentage share of FDIs inflow is more than 44 percentage of total foreign investment throughout the study period of 17 years (i.e. 2005-2017) except the year 2005 \& 2006. Researcher also identified that FDI has increased 9.92 times from 2005 to 2017 (i.e. USD 60082 million). Singh (2019) stated that higher volumes of FDI have come in service sector, computer software \& hardware sector, telecommunication sector, construction development, automobile industries etc. service sector has able to attract maximum FDI followed by manufacturing sector. Make in India programme has high potential for making India a global hub for manufacturing, research \& innovation.

\section{OBJECTIVE OF THE STUDY}

The main objective of the present study is to analyse the impact of FDI inflows on GDP, that is, to understand the impact of FDI on Indian economy since the implementation of LPG policy in India.

\section{ANALYSIS AND FINDINGS}

FDI as an essential part of investment is required by India for its sustainable financial development and improvement. FDI is vital for creation extension and of manufacturing units, medical care facilities, education, R\&D, infrastructure, retailing and in longterm sustainability.

The current study is empirical in nature and looks at what FDI means for the Indian economy by portraying FDI inflows and development elements of Indian economy. To analyse the relationship between them, annual as well as per capita GDP figures and FDI inflow figures has been taken under consideration. The study period is from 1991-92 to 2019-20, that is, from the year of implementation of LPG policy in India. Under this study linear regression model has been used to test the research hypothesis.

Research Hypothesis:

$H_{01}$ : There is no significant relationship between FDI and Annual GDP, that is, they are independent of each other.

$H_{02}$ : There is no significant relationship between FDI and Per Capita GDP, that is, they are independent of each other.

Figure 1: FDI inflow (1991-92 to2019-20)

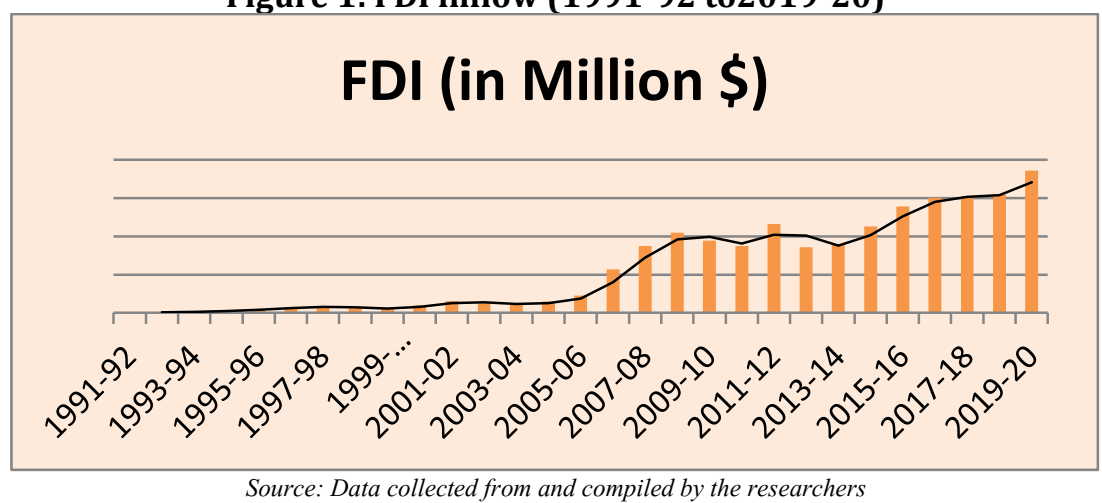

The above table shows that FDI inflows in India through various routes have grew tremendously post the 1991 reforms significantly. To the extent that growth pattern of FDI is witnessed, there has been very amazing development of FDI inflow into the
Indian economy during this post-liberalization period starting from 1991-92 to 2019-20. However, India is a long ways behind in contrast other developing nations like China.

Table 1: Regression - Model Summary ${ }^{b}$

\begin{tabular}{|c|c|c|c|c|c|}
\hline & & & & F Sig. \\
Model & R & R Square & Adjusted R Square & $\begin{array}{c}\text { Std. Error of } \\
\text { the Estimate }\end{array}$ & \\
\hline 1 & $.970(\mathrm{a})$ & .941 & .938 & 216603.10575 & $.000(\mathrm{a})$ \\
\hline
\end{tabular}

a Predictors: (Constant), Foreign Direct Investment

b Dependent Variable: Annual Gross Domestic Product

Source: Computed by the researchers through IBM SPSS 15.

Here, the dependent variable is Annual Gross Domestic Product and independent variable is Foreign Direct Investment with a constant. The Adjusted R Square value is 0.938 which implies that
93.8\% variation in Annual Gross Domestic Product is predicted from the independent variable Foreign Direct Investment. 
The $\mathrm{F}$ test is statistically significant as $\mathrm{p}$ value is less than 0.05 and hence the model is a good predictor. We can assume that the model explains a significant amount of the variance in Annual Gross
Domestic Product and hence it can be concluded that there is significant relationship between FDI and Annual GDP, that is, they are not independent of each other.

Table 2: Regression - Model Summary ${ }^{b}$

\begin{tabular}{|c|c|c|c|c|c|}
\hline Model & R & R Square & Adjusted R Square & $\begin{array}{c}\text { Std. Error of the } \\
\text { Estimate }\end{array}$ & F Sig. \\
\hline 1 & $.969(\mathrm{a})$ & .939 & .936 & 153.41213 & $.000(\mathrm{a})$ \\
\hline
\end{tabular}

a Predictors: (Constant), Foreign Direct Investment

b Dependent Variable: Per Capita Gross Domestic Product

Source: Computed by the researchers through IBM SPSS 15.

Here, the dependent variable is Per capita Gross Domestic Product and independent variable is Foreign Direct Investment with a constant. The Adjusted R Square value is 0.936 which implies that 93.6\% variation in Gross Domestic Product is predicted from the independent variable Foreign Direct Investment.

The $\mathrm{F}$ test is statistically significant as $\mathrm{p}$ value is less than 0.05 and hence the model is a good predictor. We can assume that the model explains a significant amount of the variance in Per Capita Gross Domestic Product and hence it can be concluded that there is significant relationship between FDI and Per Capita GDP, that is, they are not independent of each other.

Expanded FDI inflow in India in on-going period can be bantered to be supported by the genuinely steady Gross domestic product development rate, where it proceeded as a significant lift towards a legitimate high domestic investment. As both the null hypothesis has been statistically rejected, there is significant impact of FDI inflows in both total annual GDP and Per Capita GDP, signifying a positive impact on the Indian economy.

Increase in FDI inflows in Indian economy shows that there is a decent pattern of investment which eventually brings about expanding the Gross domestic product and development of the country, which we have found in our study that increasing trend of FDI additionally builds the Gross domestic product of the nation.

\section{CONCLUSION}

On the basis of above analysis, researchers conclude that FDI inflow has a positive impact on the GDP of the nation and in plays a significant role in overall economic development. Capital, both physical and human capital that is being moved to the host country by the FDI route, subsequently adds to the value creation of the host country, which is also evident in case of India, as supported by our analysis. Henceforth, the inflow of FDI into the economy leads to increase in per capita GDP, that is, per capita income and enhancement of purchasing power of the masses. This in turn leads to improvement of standard of living and holistic development of the nation.

\section{REFERENCES}

1. Aggrawal, S., Singla, A., Aggrawal, R. (2012). Foreign direct investment in India. International Journal of Computational Engineering \& Management, 15 (5), 93-105.

2. Azhar, S., Marimuthu, K.N. (2012). An overview of foreign direct Investment in India. International Journal of Multidisciplinary Management studies, 2 (1), 202-214.

3. Bajpai, R. (2016). A Study of FDI and its Impact on Indian Economy. Indian Journal of Applied Research, 6(1), 26-28.

4. Devajit, M. (2012). Impact of foreign direct investment on Indian economy. Research Journal of management Sciences, 1(2), 29-31.

5. Duggal, A. (2017). Foreign Direct Investment in India. Journal of Internet Banking and Commerce, 22(3).

6. Kumar, P. (2011). FDI in India and its impact"A critical evaluation". VRSD International Journal of Business \& Management Research, 1(3), 185-196.

7. Mahajan, D. (2008). FDI in India not as per her potential. The Economic Challenger, 41 (11), 5963.

8. Malhotra, B. (2014). Foreign Direct Investment: Impact on Indian Economy. Global Journal of Business Management and Information Technology, 4(1), 17-23.

9. Sahni, P. (2012). Trends and determinants of foreign direct investment in India: An empirical investigation. International Journal of Marketing and Technology, 2 (8), 144-161.

10. Singh, S. (2019). Foreign Direct Investment (FDI) Inflows in India. Journal of General Management Research, 6(1), 41-53.

11. Vyas, A.V. (2015). An Analytical Study of FDI in India. International Journal of Scientific and Research Publications, 5(10).

\section{URL VISITED}

1. http:///www.economywatch.com

2. http:///www.indiastat.com

3. http:///www.rbi.org.in

4. https://countryeconomy.com 